\title{
ONE TECHNOLOGY - TWO TYPES OF PROTECTION
}

$$
\text { ОДНА ТЕХНОЛОГИЯ - ДВА ВИДА ЗАЩИТЫ }
$$

\section{A. Glinushkin, Candidate of Agricultural Sciences}

А.П. Глинушкин, кандидат сельскохозяйственных наук

\section{A. Solovykh, V. Lukjantsev, S. Dushkin, G. Sudarenkov, Post-graduate students}

А.А. Соловых, В.С. Лукьянцев, С.А. Душкин, Г.В. Сударенков, аспиранты

Orenburg State Agrarian University, Orenburg, Russia

Оренбургский государственный аграрный университет, г. Оренбург, Россия

E-mail: orensovet@yandex.ru, ansolovykh@yandex.ru, lukans@mail.ru, s.duschkin@mail.ru, german-sudar@yandex.ru

Received March 10, 2012

\begin{abstract}
Pests of the order Lepidoptera - South barn and Grain moth moth - one of the most dangerous pests of grain mass. The data obtained show that the technology (seed disinfectants and quality) of spring wheat affects the damage Plodia interpunctella Hb. and Sitotroga cerealella Oliv.
\end{abstract}

\section{АННОТАЦИЯ}

Вредители из отряда чешуекрыльх - Южная амбарная огневка и Зерновая моль - одни из опаснейших вредителей зерновых масс. Полученные данные показывают, что технология (протравители семян и сорт) яровой пшенищы влияет на поражение Plodia interpunctella Hb. u Sitotroga cerealella Oliv.

\section{KEY WORDS}

Storage; Protection; Grain; Granary pests; Butterflies; Wheat.

\section{КЛЮЧЕВЫЕ СЛОВА}

Хранение; Защита; Зерно; Амбарные вредители; Бабочки; Пшеница.

Агроэкологическая основа производства зерна занимает лидирующие позиции среди ведущих ученых РФ (Долженко В.И., Новожилов К.А., Сухорученко Г.И. и др., 2011).

Сезонность производства зерна, с одной стороны, и потребление его в течение всего года, с другой, требуют организовать длительное хранение больших масс зерна в элеваторах. Анализ баланса зернового рынка Российской Федерации по данным Объединенной зерновой компании показывает, что переходящие запасы зерновых за последние три года в среднем составили 19,1 млн. т., т.е. такое количество зерна ежегодно необходимо защищать от вредных организмов.
В последние годы многое изменилось в теории и практике защиты зерна от вредителей, накопились новые знания в этой области как в нашей стране, так и за рубежом. Скромно предложение агроэкологического плана, преобладают радикальные и практически приемлемые средства уничтожения вредителей запасов, на базе применения ядовитых веществ - пестицидов. При этом возникают опасности производства, транспортировки, хранения и применения пестицидов. Существует опасность превышения максимально допустимых уровней (МДУ) их в зерновой продукции (Закладной, 1983; 2006; Левченко, 1965).

Вредители из отряда чешуекрылых одни из опаснейших вредителей зерновых масс. Южная амбарная огневка (Plodia 
interpunctella $H b$.) карантинный объект для Монголии, Словакии, КНДР, Венгрии, Чехии. Зерновая моль (Sitotroga cerealella Oliv.) является карантинным объектом для КНДР и Венгрии. Бабочки чаще повреждают верхний слой зерновой насыпи на глубину до $20 \mathrm{~cm}$. Поврежденное зерно оплетается паутиной, засоряется экскрементами. В результате питания гусениц наблюдается снижение веса зерна до $56 \%$. При сильном заселении перед массовым выходом бабочек Зерновой моли происходит значительное повышение температуры зерна, что ведет к образованию очагов самосогревания. Вследствие жизнедеятельности огневок повышается влажность, т.е. улучшаются условия для существования микрофлоры. Экспериментально доказано, что влажные экскременты гусениц молей и огневок привлекают амбарных клещей. При размножении плесневых грибов и бактерий продукты приобретают затхлый запах, становятся комковатыми, становятся непригодными для пищевых и фуражных целей. Токсические вещества, содержащиеся в теле и экскрементах некоторых огневок, могут приводить к желудочно кишечным расстройствам, а при попадании на кожу вызывать различные дерматиты, пищеварительные ферменты являются аллергенами (Буракова, 2009; Соколов, 2004).

Наши усилия направлены на агроэкологические подходы и системы защиты растений (Глинушкин А.П., 2009 а, б), которые предусматривают, выявление перспективных в таком отношении сортов пшеницы и технологий производства яровой пшеницы.

Материалы и методы исследований. Исследования проводились в 2007-2009 гг. на сортах яровой пшеницы Оренбургская 13, Варяг, Саратовская 42. Полевые опыты закладывались в условиях учебно - опытного поля, лабораторные в лаборатории защиты растений Оренбургского ГАУ. Проводилось протравливание семян машиной ПС-10 различными протравителями, в частности: ТМТД 3 л/т, ТМТД Плюс 2,5 л/т, Виал ТТ 0,4 л/т, Дивиденд Стар 0,75 л/т, ТМТД Плюс 2 л/т + Виал ТТ 0,2 л/т. Уборку урожая на опытных делянках проводили прямым комбайнированием комбайном САМПО 2000. Зерно взвешивали с каждой делянки, после чего отбирались средние образцы для определения влажности, засоренности, технологических качеств зерна и определения повреждаемости бабочками в условиях свободного заселения.

Опыт закладывался согласно методике Б.А. Доспехова (1985) в трехкратной повторности. В полиэтиленовый мешочек помещалось 600 г зерна каждого варианта и открыто оставляли для свободного заражения южной огневкой и зерновой молью. Данные вредители в большом количестве обитали в опытной комнате. Время проведения опыта 6 месяцев. Температура в помещении поддерживалась оптимальной для развития вредителей. При анализе каждый образец взвешивался. Для определения степени поврежденности образца отбиралось 100 зерен подряд в трехкратной повторности. Отобранные зерна анализировались на предмет выедания зародыша (повреждение южной амбарной огневкой) и проедания эндосперма (характерное повреждение зерновой молью). У пораженных вредителем зерновок зародыш был либо полностью выеден, либо немного поврежден, что устанавливалось при рассматривании каждого зернышка через лупу. После анализа выводились средние данные, что соответствовало проценту поражения, т.к. брали для анализа 100 зерен.

Статистическая обработка полученных результатов проведена методами дисперсионного и корреляционного анализов по Б.А. Доспехову (1985) с использованием пакета статистических программ Microsoft Excel 2010.

Результаты исследований. Анализ полученных данных показывает, что сорта поражались различно, как южной амбарной огневкой, так и зерновой молью. Сорт яровой пшеницы Варяг менее поражался, чем Оренбургская 13 и Саратовская 42. Выявлена сильная корреляционная зависимость между сортом яровой пшеницы и поражением Зерновой молью $(\mathrm{r}=0,9)$. Корреляционная зависимость между сортом яровой пшеницы и поражением Южной амбарной огневкой выявлена средняя $(\mathrm{r}=0,6)$.

Общее повреждение сорта Оренбургская 13 было наибольшим на вариантах 
контроль и ТМТД Плюс (85 и 78 \% соответственно). Повреждение Южной амбарной огневкой было наибольшим на контрольном варианте (53\%), наименьшим на варианте ТМТД Плюс (6\%). Варианты
ТМТД и Виал ТТ Зерновая моль не повреждала. Наибольшее повреждение Зерновой молью было на варианте ТМТД Плюс $(72 \%)$.

\begin{tabular}{|c|c|c|c|}
\hline Вариант опыта & Повреждено, \% & $\begin{array}{c}\text { Южной амбарной } \\
\text { огневкой, \% }\end{array}$ & Зерновой молью, \% \\
\hline \multicolumn{4}{|c|}{ сорт Oренбургская 13} \\
\hline Контроль & 85 & 53 & 32 \\
\hline ТМТД & 30 & 30 & - \\
\hline ТМТД Плюс & 78 & 6 & 72 \\
\hline Виал Тт & 36 & 36 & - \\
\hline Дивиденд Стар & 42 & 40 & 2 \\
\hline ТМТД Плюс + Виал ТТ & 50 & 46 & 4 \\
\hline \multicolumn{4}{|c|}{$\begin{array}{l}\mathrm{HCP}_{05}-10,19 \% ; \mathrm{P}-5,72 \%(2007 \text { г.) } \\
\mathrm{HCP}_{05}-5,26 \% ; \mathrm{P}-3,22 \%(2008 \text { г.) } \\
\mathrm{HCP}_{05}-4,29 \% ; \mathrm{P}-2,61 \%(2009 \text { г.) }\end{array}$} \\
\hline \multicolumn{4}{|c|}{ сорт Варяг } \\
\hline Контроль & 52 & 52 & - \\
\hline ТМТД & 25 & 25 & - \\
\hline ТМТД Плюс & 34 & 30 & 4 \\
\hline Виал ТT & 27 & 27 & - \\
\hline Дивиденд Стар & 14 & 14 & - \\
\hline ТМТД Плюс + Виал ТТ & 12 & 12 & - \\
\hline \multicolumn{4}{|c|}{$\begin{array}{l}\mathrm{HCP}_{05}-6,7 \% ; \mathrm{P}-8,29 \%(2007 \text { г. } \\
\mathrm{HCP}_{05}-6,85 \% ; \mathrm{P}-7,85 \%(2008 \text { г.) } \\
\mathrm{HCP}_{05}-5,57 \% ; \mathrm{P}-6,16 \%(2009 \text { г.) }\end{array}$} \\
\hline \multicolumn{4}{|c|}{ сорт Саратовская 42} \\
\hline Контроль & 38 & 32 & 6 \\
\hline ТМТД & 82 & 20 & 62 \\
\hline ТМТД Плюс & 98 & 14 & 84 \\
\hline Виал ТT & 30 & 28 & 2 \\
\hline Дивиденд Стар & 54 & 54 & - \\
\hline ТМТД Плюс + Виал ТТ & 34 & 30 & 4 \\
\hline \multicolumn{4}{|c|}{$\begin{array}{l}\mathrm{HCP}_{05}-9,04 \% ; \mathrm{P}-4,99 \%(2007 \text { г.) } \\
\mathrm{HCP}_{05}-6,35 \% ; \mathrm{P}-3,53 \%(2008 \text { г.) } \\
\mathrm{HCP}_{05}-8,57 \% ; \mathrm{P}-5,08 \%(2009 \text { г.) }\end{array}$} \\
\hline
\end{tabular}

Сорт Варяг имел максимальное повреждение Южной амбарной огневкой на контрольном варианте (52\%), менее остальных повреждался вариант Дивиденд Стар. Зерновой молью поражался только вариант ТМТД Плюс (4\%), остальные варианты не повреждались.

Общее повреждение сорта Саратовская 42 было наибольшим на варианте ТМТД Плюс (98\%), наименьшее на варианте Виал ТТ (30\%). Больше остальных повреждался Южной амбарной огневкой вариант Дивиденд Стар (54\%), но этот вариант не повреждался зерновой молью, наименьшее повреждение имел вариант ТМТД Плюс (14\%). Наибольшее повреж- дение Зерновой молью отмечено на вариантах ТМТД и ТМТД Плюс (62 и 84\% соответственно).

Результаты исследований 2007-2009 гг. по изучению повреждаемости зерна яровой пшеницы Южной амбарной огневкой и Зерновой молью в зависимости от элементов технологии производства позволяют говорить о том, что протравливание семян перед посевом влияет не только на развитие и распространение болезней, но и на заселение зерна во время хранения вредителями. Последействие технологий производства также имеет важнейшее значение для эффективной защиты произведенного зерна. 


\section{БИБЛИОГРАФИЯ}

Буракова, О.В. Огневки - вредители запасов // Пест-менеджмент, - 2009. №1-2, С. 18-24

Долженко В.И. Химическая защита растений в фитосанитарном оздоровлении агроэкосистем/ В.И.Долженко, К.В.Новожилов, Г.И.Сухорученко, С.Л.Тютерев/ Вестник защиты растений. № 3, 2011 г., с. 3-12.

Доспехов, Б.А. Методика полевого опыта (с основами статистической обработки результатов исследований). - 5-е изд. доп. и перераб. М.:Агропром-издат, 1985. - 351 с.

Глинушкин, А.П. (а) Эффективность применения средств защиты в технологиях возделывания яровой мягкой пшеницы //Известия Оренбургского государственного аграрного университета. - 2009. - №1(21). - С. 25-27.

Глинушкин, А.П. (б) Эффективность пестицидов при производстве яровой мягкой пшеницы //Известия Оренбургского государственного аграрного университета. - 2009. №2(22). - C. 39-42.
Глинушкин, А.П. Эффективность элементов интегрированной защиты яровой мягкой пшеницы //Вестник Оренбургского государственного университета. - Оренбург. - №2. 2010. - С. 32-36.

Закладной, Г.А. Вредители хлебных запасов, Издание второе, дополненное //приложение Защита и карантин растений, № 6, 2006 г.

Закладной, Г.А. Защита зерна и продуктов его переработки от вредителей.М.: Колос, 1983.- 215 с., ил.8 л. ил.

Левченко, Е.А. Борьба с вредителями хлебных запасов. - М.: Колос, 1965.$144 \mathrm{c}$.

Соколов, Е.А. Вредители запасов, их карантинное значение и меры борьбы/ Под общей редакцией и с предисловием М.И. Маслова. - Оренбург: Печатный дом «Димур», 2004.- 104 с., ил.: $28 \mathrm{c.}$ 